Original Article

\title{
Polymorphisms in Four Genes Related to Triglyceride and HDL-cholesterol Levels in the General Japanese Population in 2000
}

\author{
Hidenori Arai ${ }^{1}$, Akira Yamamoto 2 , Yuji Matsuzawa ${ }^{3}, Y^{2}$ asushi Saito ${ }^{4}$, Nobuhiro Yamada ${ }^{5}$, \\ Shinichi Oikawa ${ }^{6}$, Hiroshi Mabuchi ${ }^{7}$, Tamio Teramoto ${ }^{8}$, Jun Sasaki ${ }^{9}$, Noriaki Nakaya ${ }^{10}$, \\ Hiroshige Itakura ${ }^{11}$, Yuichi Ishikawa ${ }^{12}$, Yasuyoshi Ouchi ${ }^{13}$, Hiroshi Horibe ${ }^{14}$, Tohru Egashira ${ }^{15}$, \\ Hiroaki Hattori ${ }^{15}$, Nobuo Shirahashi ${ }^{16}$, and Toru Kita ${ }^{17}$ on behalf of the Research group on \\ Serum Lipid Level Survey 2000 in Japan
}

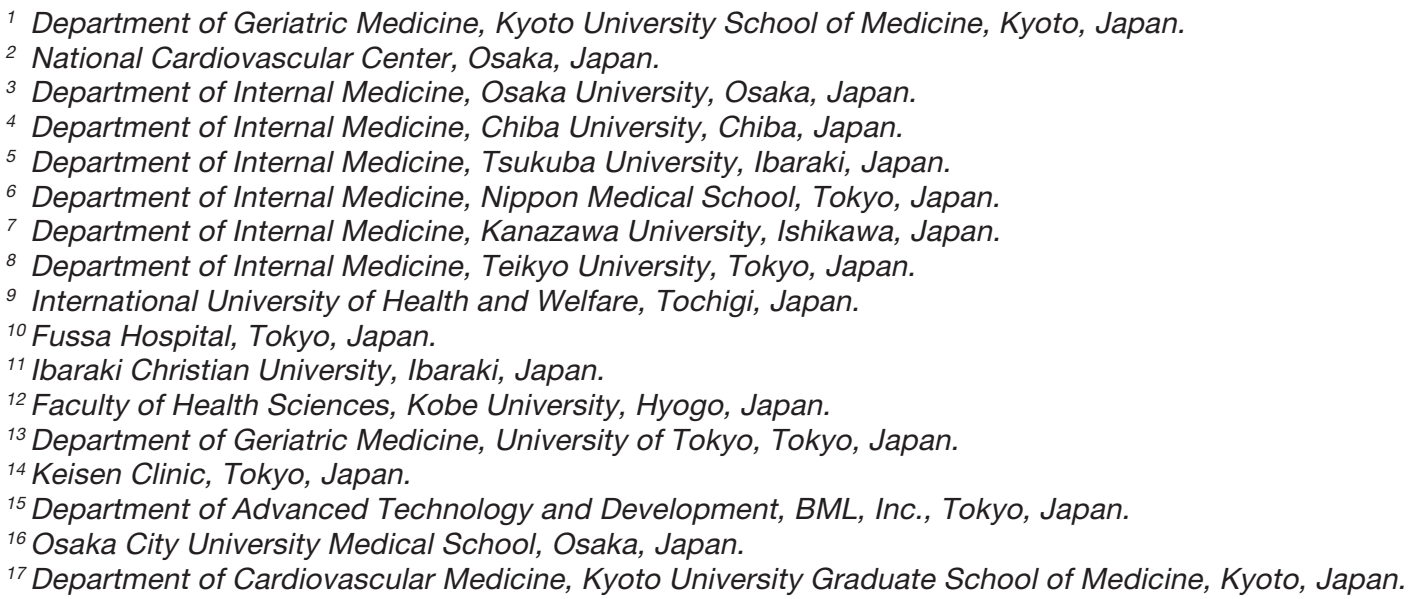

We studied the association of six common polymorphisms of four genes related to lipid metabolism with serum lipid levels. We selected single-nucleotide polymorphisms (SNPs) in the genes for cholesteryl ester transfer protein (CETP), lipoprotein lipase (LPL), hepatic lipase (LIPC), and apolipoprotein CIII (APOC3), and studied 2267 individuals randomly selected from the participants of Serum Lipid Survey 2000. There was a significant association of CETP polymorphism (D442G, Int14 $+1 \mathrm{G} \rightarrow \mathrm{A}$, and TaqIB), LPL polymorphism (S447X), and LIPC polymorphism (-514 $\rightarrow$ CT) with HDLcholesterol levels. We also found a significant association of LPL polymorphism (S447X) and $A P O C 3$ polymorphism (Sstl) with triglyceride levels. This is the largest database showing the association of common genetic variants in lipid metabolism with serum lipid levels in the general Japanese population. Further study is necessary to elucidate the role of these gene polymorphisms in cardiovascular events. $J$ Atheroscler Thromb, 2005; 12: 240-250.

Key words; Hyperlipidemia, Polymorphism, Cholesterol ester transfer protein, Lipoprotein lipase, Triglyceride lipase, Apolipoprotein CIII

Address for correspondence: H. Arai, Department of Geriatric Medicine, Kyoto University School of Medicine, 54 Kawahara-cho, Shogoin, Sakyo-ku, Kyoto 606-8507, Japan.

E-mail: harai@kuhp.kyoto-u.ac.jp

Received April 1, 2005

Accepted for publication July 1, 2005

\section{Introduction}

Hyperlipidemia is a major risk factor for coronary artery disease (CAD) (1). In contrast to the sharp decline in both serum cholesterol levels and mortality from CAD in the United States and Western Europe, remarkable increases 
in serum cholesterol levels as well as CAD mortality have been anticipated in the Asian-Pacific area due to industrialization and the modernization of lifestyle (2). The importance of lifestyle is also proved by the fact that Japanese who migrated to Hawaii and California, for example, showed higher levels of serum cholesterol and a higher incidence of CAD than people in Japan (3). Thus, dietary habits and other environmental factors affect serum cholesterol levels and CAD mortality in the population. However, genetic traits are also an important determinant of serum lipid levels.

Major mutations have been described coding for the low-density lipoprotein (LDL) receptor, apolipoprotein B, and so forth, affecting mainly serum LDL-cholesterol levels $(4,5)$. However, plasma triglyceride (TG) and highdensity lipoprotein (HDL)-cholesterol levels are also considered established risk factors for CAD (6). Therefore, the association of common variants of candidate genes with changes in TG and HDL-cholesterol levels would be important determinants for CAD risk. Considering the recent prevalence of metabolic syndrome, it would be also intriguing to examine the effect of these genetic polymorphisms on the development of metabolic syndrome. So far in Japan, however, a large-scale analysis has not been performed on common gene variants related to lipid metabolism.

In 2000, we conducted a survey in the general Japanese population, involving 12,839 people from all over the country (7). We tried to examine the frequency of common polymorphisms of four genes related to lipid metabolism and show an association with serum lipid levels. Among the factors involved in lipid metabolism, we chose the following 4 genes because of the association with TG or HDL-cholesterol. Cholesteryl ester transfer protein (CETP) facilitates the transfer of cholesteryl ester from HDL to apolipoprotein B-containing lipoproteins (8). CETP is a key protein in reverse cholesterol transport and its deficiency is associated with hyperalphalipoproteinemia (9-11). Among several polymorphisms of the CETP gene, a $\mathrm{G}$ to $\mathrm{A}$ substitution at the 5 ' splice donor site of intron $14(\operatorname{Int} 14+1 \mathrm{G} \rightarrow \mathrm{A})$ and a missense mutation in exon 15 (D442G) are common mutations of hyperalphalipoproteinemia in Japanese (12, 13). The Int14 $+1 \mathrm{G} \rightarrow \mathrm{A}$ mutation results in a null allele: homozygotes with the mutation have no CETP in plasma and markedly elevated levels of HDL-cholesterol (10). The D442G mutation is near the carboxy terminal region of CETP shown to be essential for its function $(14,15)$. The TaqIB polymorphism of the CETP gene is one of the most studied polymorphisms worldwide. The B2 allele of the TaqIB polymorphism in intron 1 was associated with decreased CETP levels and high HDL-cholesterol levels (16) and with coronary heart disease risk in the Framingham Study (17). Therefore, we selected these three polymorphisms for our analysis.
Lipoprotein lipase (LPL) is one of the key enzymes in the metabolism of TG-rich lipoproteins. Among several polymorphisms of the LPL gene we chose S447X, which is common, having an allele frequency of approximately $20 \%$ in healthy individuals, and whose mutation is associated with a favorable lipid profile (18-20). Hepatic lipase (LIPC) is also a member of the lipase superfamily and plays an important role in the metabolism and modeling of both pro- and anti-atherogenic lipoproteins (21). Among the several polymorphisms we selected, $-514 \mathrm{C}$ $\rightarrow \mathrm{T}$, located in the promoter region of the LIPC gene, has been demonstrated to influence LIPC activity levels (22). Apolipoprotein CIII (apoCIII) can inhibit LPL and reduces the uptake of TG-rich remnant particles and the SstI polymorphism of the APOC3 gene has been shown to be associated with hypertriglyceridemia and CAD in various human populations (23-27). Therefore, we also examined these polymorphisms in the general Japanese population.

The aim of this study was, therefore, to examine the incidence of these gene polymorphisms and their contribution to lipid concentrations in the general Japanese population.

\section{Methods}

\section{Designs and data collection}

This work is part of the Serum Lipid Survey 2000 from various areas around Japan. The Ethics committee, graduate school and faculty of Medicine, Kyoto University approved the study protocol and all subjects provided written informed consent for the genetic analysis. The DNA samples were handled according to the guidelines from the Ministry of Health, Labor, and Welfare. In the Serum Lipid Survey 2000, a total of 12,839 subjects were recruited at 36 hospitals across the country. The subjects in the present study were participants in the survey at 9 hospitals from whom informed content for genotyping was sought. Of 12,839 subjects, 2267 (17.7\%) with no lipid-altering medication were randomly selected for the present study. In some institutes, information on gender was not disclosed.

\section{Laboratory methods}

All serum and blood samples were obtained in the fasting state. All lipid and other analyses were conducted with venous blood samples within one week of collection at BML (Saitama, Japan). Serum cholesterol and TG levels were measured by enzymatic assay. HDL-cholesterol and LDL-cholesterol levels were measured enzymatically with a kit from Daiichi Kagaku Co. Ltd. (Tokyo, Japan). The results of lipid analyses were indirectly standardized according to the criteria of the CDC Lipid Standardization Program (25). DNA was extracted with a QIAamp DNA blood kit (Qiagen, Hilden, Germany). 


\section{Detection of gene mutations by Invader ${ }^{\circledR}$ assay}

We used the Invader ${ }^{\circledR}$ assay to screen three known mutations of the CETP gene, one mutation of the LIPC gene, one mutation of the $L P L$ gene, and one mutation of the APOC3 gene, as previously described (26). In brief, the probe/Invader ${ }^{\circledR} / \mathrm{MgCl}_{2}$ mixture was prepared by combining $3 \mu \mathrm{l}$ of primary probe/Invader ${ }^{\circledR}$ mix and $5 \mu \mathrm{l}$ of 22.5 $\mathrm{mM} \mathrm{MgCl} 2$ per reaction. The primary probes/Invader ${ }^{\circledR}$ mixture contained $3.5 \mu \mathrm{mol} / \mathrm{l}$ wild primary probe, 3.5 $\mu \mathrm{mol} / / \mathrm{l}$ mutant primary probe, $0.35 \mu \mathrm{mol} / / \mathrm{Invader}{ }^{\circledR}$ oligonucleotide, and $10 \mathrm{mmol} / \mathrm{I}$ MOPS. Eight microliters of primary probe/Invader ${ }^{\circledast} / \mathrm{MgCl}_{2}$ mixture as well was added into a 96-well plate. Seven microliters of $5 \mathrm{fmol} / \mathrm{l} \mathrm{syn-}$ thetic target oligonucleotides, $10 \mu \mathrm{g} / \mathrm{ml}$ yeast tRNA (no target blank), and genomic DNA (15 ng/ $\mathrm{\mu l}$ ) were added, and denatured by incubation at $95^{\circ} \mathrm{C}$ for $10 \mathrm{~min}$. After 15 $\mu \mathrm{l}$ of mineral oil (Sigma, St. Louis, MO, USA) was overlayed into each well, the plate was incubated isothermally at $63^{\circ} \mathrm{C}$ for $4 \mathrm{~h}$ in a DNA thermalcycler (PTC200; MJ Research, Watertown, MA, USA) and then kept at $4^{\circ} \mathrm{C}$ until fluorescence was measured. The fluorescent intensities were measured using a fluorescence microtiter plate reader (Cytoflour 4000; Applied Biosystems) with excitation at $485 \mathrm{~nm} / 20 \mathrm{~nm}$ (Wave length/Band width) and emission, at $530 \mathrm{~nm} / 25 \mathrm{~nm}$ for FAM, and excitation at $560 \mathrm{~nm} / 20 \mathrm{~nm}$ and emission, at $620 \mathrm{~nm} / 40 \mathrm{~nm}$ for RED. The genotyping was based on calculations with the ratios of net counts with wild primary probe to net counts with mutant primary probe. The probes used in this study were designed and synthesized by Third Wave Technologies, Inc (Madison, WI).

\section{Data analyses}

Differences in means were evaluated using an analysis of variance. Multiple regression analysis was done to compare age- and sex-adjusted means. The $\chi^{2}$-test was used to compare the incidence of each genotype. The analysis was performed with the statistical Package for Social Sciences (SPSS Japan Inc. ver. 11.5, Tokyo, Japan).

\section{Results}

We investigated the frequency and phenotypic association of the common polymorphisms of CETP, LPL, LIPC, and APOC3 genes at the population level in 2,267 subjects. Table 1 summarizes the mean serum lipid levels in the participants in this study. The mean age, and total cholesterol, TG, HDL-cholesterol, and LDL-cholesterol levels in this population were similar to the values for all 12,839 participants in Serum Lipid Survey 2000. We also found that the medians of total, LDL-, and HDLcholesterol levels did not differ appreciably from the means, thereby excluding gross right-hand tailing of the distribution (data not shown). These results indicate that
Table 1. Lipid profile and age of all the participants.

\begin{tabular}{lcll}
\hline & All & \multicolumn{1}{c}{ Men } & Women \\
\hline T-Cho $(\mathrm{mmol} / \mathrm{l})$ & $5.18(0.021)$ & $5.23(0.046)$ & $5.15(0.046)$ \\
$\mathrm{TG}(\mathrm{mmol} / \mathrm{l})$ & $1.31(0.024)$ & $1.58(0.050) *$ & $1.11(0.039) *$ \\
$\mathrm{HDL}-\mathrm{c}(\mathrm{mmol} / \mathrm{l})$ & $1.53(0.010)$ & $1.38(0.020) *$ & $1.65(0.017) *$ \\
LDL-c (mmol/l) & $3.00(0.020)$ & $3.08(0.044) *$ & $2.93(0.039) *$ \\
Age (years) & $47.1(0.58)$ & $49.5(0.87) *$ & $45.3(0.76)^{*}$ \\
Men (\%) & 43 & & \\
\hline
\end{tabular}

Data are expressed as the mean (SEM).

$* p<0.01$, men vs. women.

the participants in the gene analysis are representative of the general Japanese population.

Table 2 summarizes the association of the gene polymorphisms with serum lipid levels in all the participants. Tables 3 and 4 show the analysis in male and female participants, respectively. Table 5 shows age- and sexadjusted means with $95 \% \mathrm{Cl}$. We found that HardyWeinberg equilibrium was the case for all the SNPs, supporting the assumptions of random mating in this population except CETP Int14 $+1 \mathrm{G} \rightarrow \mathrm{A}$, for which no homozygote was found in this population.

The incidence of heterozygote mutations of D442G and Int $14+1 \mathrm{G} \rightarrow \mathrm{A}$ of the CETP gene was 8.1 and $0.6 \%$, respectively. These mutations were associated with higher HDL-cholesterol levels. The heterozygous mutation of D442G was also associated with lower TG levels only in men. Although the incidence of the homozygous mutation of $D 442 G$ and heterozygous mutation of Int 14 $+1 \mathrm{G} \rightarrow \mathrm{A}$ was quite low and the difference was not significant, the TG levels tended to be higher. The incidence of B1B1, B1B2, and B2B2 genotypes of the CETP TaqIB polymorphism was $35.8,48.4$, and $15.8 \%$, respectively. The B2 allele of the CETP TaqIB polymorphism was associated with higher HDL-cholesterol levels in all the participants, men, and women. Although the difference was not statistically significant, the participants with the B2 allele tended to have lower TG levels, which is different from the results with the homozygous mutation of $\mathrm{D} 442 \mathrm{G}$ and heterozygous mutation of Int $14+1 \mathrm{G} \rightarrow \mathrm{A}$.

We then determined the polymorphisms of LPL S447X mutations in this population. The incidence of heterozygous and homozygous mutations in the LPL gene was 20.7 and $1.3 \%$, respectively. The mutation of the LPL S447X site was associated with higher HDL-cholesterol and lower TG levels, although the difference in the level of HDL-cholesterol in men or of TG in women was not statistically significant, possibly due to the small sample number.

The incidence of the CC, CT, and TT genotypes of LIPC in the Japanese was $24.9,50.4$, and $24.7 \%$, respectively. Overall, the T allele was associated with an increase in HDL-cholesterol levels. However, the difference was not 
Table 2. Demographic and lipid profile of all the participants according to genotype.

CETP D442G (rs2303790)

\begin{tabular}{|c|c|c|c|c|c|}
\hline Genotype & Age & $\%$ & HDL-c (mmol/l) & $\mathrm{TG}(\mathrm{mmol} / \mathrm{l})$ & LDL-c (mmo/l) \\
\hline wt & 47 & 91.6 & $1.53(0.001)$ & $1.37(0.025)$ & $3.06(0.021)$ \\
\hline hetero & 48.4 & 8.1 & $1.75(0.004)$ & $1.15(0.061)$ & $2.90(0.075)$ \\
\hline \multirow[t]{2}{*}{ homo } & 46.5 & 0.2 & $1.81(0.18)$ & $1.60(0.101)$ & $3.19(1.580)$ \\
\hline & & & $p=0.000$ & $p=0.071$ & $p=0.154$ \\
\hline \multicolumn{6}{|c|}{ CETP Int14 +1 G $\rightarrow$ A (rs5742907) } \\
\hline Genotype & Age & $\%$ & HDL-c (mmol/l) & $\mathrm{TG}(\mathrm{mmol} / \mathrm{l})$ & LDL-c (mmo/l) \\
\hline wt & 47 & 99.4 & $1.54(0.009)$ & $1.36(0.024)$ & $3.06(0.020)$ \\
\hline \multirow[t]{2}{*}{ hetero } & 58.7 & 0.6 & $2.12(0.262)$ & $1.72(0.362)$ & $3.08(0.316)$ \\
\hline & & & $p=0.000$ & $p=0.241$ & $p=0.938$ \\
\hline \multicolumn{6}{|c|}{ CETP TaqIB (rs708272) } \\
\hline Genotype & Age & $\%$ & HDL-c (mmol/l) & $\mathrm{TG}(\mathrm{mmol} / \mathrm{l})$ & LDL-c (mmo/l) \\
\hline B1B1 & 46.8 & 35.8 & $1.50(0.016)$ & $1.36(0.036)$ & $3.00(0.033)$ \\
\hline B1B2 & 48.4 & 48.4 & $1.54(0.013)$ & $1.38(0.038)$ & $3.08(0.030)$ \\
\hline \multirow[t]{2}{*}{ B2B2 } & 48.2 & 15.8 & $1.66(0.024)$ & $1.25(0.043)$ & $3.08(0.051)$ \\
\hline & & & $p=0.000$ & $p=0.160$ & $p=0.362$ \\
\hline \multicolumn{6}{|c|}{ LPL S447X (rs328) } \\
\hline Genotype & Age & $\%$ & HDL-c (mmol/l) & $\mathrm{TG}(\mathrm{mmol} / \mathrm{l})$ & LDL-c (mmo/l) \\
\hline wt & 47.3 & 78 & $1.53(0.011)$ & $1.37(0.029)$ & $3.06(0.023)$ \\
\hline hetero & 46.2 & 20.7 & $1.60(0.020)$ & $1.24(0.043)$ & $3.06(0.046)$ \\
\hline \multirow[t]{2}{*}{ homo } & 48 & 1.3 & $1.63(0.101)$ & $1.08(0.125)$ & $3.29(0.189)$ \\
\hline & & & $p=0.004$ & $p=0.032$ & $p=0.487$ \\
\hline \multicolumn{6}{|c|}{ LIPC 514CT (rs1800588) } \\
\hline Genotype & Age & $\%$ & HDL-c (mmol/l) & $\mathrm{TG}(\mathrm{mmol} / \mathrm{l})$ & LDL-c (mmo/l) \\
\hline $\mathrm{CC}$ & 49.7 & 24.9 & $1.49(0.018)$ & $1.37(0.046)$ & $3.11(0.040)$ \\
\hline CT & 45.6 & 50.4 & $1.53(0.013)$ & $1.33(0.034)$ & $3.03(0.029)$ \\
\hline \multirow[t]{2}{*}{$\mathrm{TT}$} & 47.6 & 24.7 & $1.63(0.020)$ & $1.39(0.050)$ & $3.06(0.040)$ \\
\hline & & & $p=0.000$ & $p=0.520$ & $p=0.255$ \\
\hline \multicolumn{6}{|c|}{ APOC3 SstI (rs5128) } \\
\hline Genotype & Age & $\%$ & HDL-c (mmol/l) & $\mathrm{TG}(\mathrm{mmol} / \mathrm{l})$ & LDL-c (mmo/l) \\
\hline S1S1 & 46.6 & 42 & $1.56(0.015)$ & $1.32(0.039)$ & $3.06(0.032)$ \\
\hline S1S2 & 47 & 45.8 & $1.54(0.013)$ & $1.34(0.033)$ & $3.03(0.029)$ \\
\hline \multirow[t]{2}{*}{ S2S2 } & 48.9 & 12.2 & $1.52(0.025)$ & $1.53(0.070)$ & $3.11(0.060)$ \\
\hline & & & $p=0.413$ & $p=0.021$ & $p=0.434$ \\
\hline
\end{tabular}

Data are expressed as the mean (SEM). Each $p$-value was based on an analysis of covariance.

significant in men. The TG levels do not seem to be affected by this SNP.

The incidence of the S1S1, S1S2, and S2S2 genotypes of the APOC3 SstI polymorphism was 42.0, 45.8, and $12.2 \%$, respectively. Although the HDL and LDL-cholesterol levels were similar for all the genotypes, the S2 al- lele was associated with higher TG levels in all the participants and in men, but not in women. Among the SNPs studied, no polymorphism was found to affect LDL-cholesterol levels. We also determined sex- and age-adjusted means in Table 5 by multiple regression analysis. Due to the limited sample number and large variability of data, a 
Table 3. Demographic and lipid profile of male participants according to genotype.

CETP D442G (rs2303790)

\begin{tabular}{lrccc}
\hline Genotype & \multicolumn{1}{c}{$n$} & HDL-c $(\mathrm{mmol} / \mathrm{l})$ & $\mathrm{TG}(\mathrm{mmol} / \mathrm{l})$ & $\mathrm{LDL}-\mathrm{c}(\mathrm{mmo} / \mathrm{l})$ \\
\hline wt & 351 & $1.36(0.020)$ & $1.60(0.052)$ & $3.11(0.045)$ \\
hetero & 26 & $1.60(0.105)$ & $1.19(0.176)$ & $2.98(0.194)$ \\
& & $p=0.003$ & $p=0.035$ & $p=0.453$ \\
\hline
\end{tabular}

CETP TaqIB (rs708272)

\begin{tabular}{lrccc}
\hline Genotype & $n$ & HDL-c $(\mathrm{mmol} / \mathrm{l})$ & TG $(\mathrm{mmol} / \mathrm{l})$ & LDL-c $(\mathrm{mmo} / \mathrm{l})$ \\
\hline B1B1 & 121 & $1.33(0.034)$ & $1.64(0.087)$ & $3.06(0.073)$ \\
B1B2 & 203 & $1.36(0.026)$ & $1.55(0.068)$ & $3.11(0.064)$ \\
B2B2 & 53 & $1.56(0.063)$ & $1.53(0.147)$ & $3.13(0.107)$ \\
& & $p=0.001$ & $p=0.664$ & $p=0.758$ \\
\hline
\end{tabular}

LPL S447X (rs328)

\begin{tabular}{lrccc}
\hline Genotype & \multicolumn{1}{c}{$n$} & HDL-c $(\mathrm{mmol} / \mathrm{l})$ & TG $(\mathrm{mmol} / \mathrm{l})$ & LDL-c $(\mathrm{mmo} / \mathrm{l})$ \\
\hline wt & 292 & $1.36(0.022)$ & $1.65(0.060)$ & $3.08(0.047)$ \\
hetero & 81 & $1.43(0.048)$ & $1.36(0.082)$ & $3.16(0.112)$ \\
homo & 4 & $1.51(0.386)$ & $0.95(0.295)$ & $2.80(0.513)$ \\
& & $p=0.278$ & $p=0.029$ & $p=0.617$ \\
\hline
\end{tabular}

LIPC 514CT (rs1800588)

\begin{tabular}{lrccc}
\hline Genotype & \multicolumn{1}{c}{$n$} & HDL-c $(\mathrm{mmol} / \mathrm{l})$ & $\mathrm{TG}(\mathrm{mmol} / \mathrm{l})$ & LDL-c $(\mathrm{mmo} / \mathrm{l})$ \\
\hline CC & 99 & $1.32(0.032)$ & $1.66(0.094)$ & $3.08(0.072)$ \\
CT & 188 & $1.40(0.032)$ & $1.51(0.075)$ & $3.08(0.069)$ \\
TT & 90 & $1.40(0.041)$ & $1.60(0.095)$ & $3.08(0.085)$ \\
& & $p=0.266$ & $p=0.499$ & $p=0.996$ \\
\hline
\end{tabular}

\begin{tabular}{lcccc}
\multicolumn{5}{l}{ APOC3 SstI (rs5128) } \\
\hline Genotype & $n$ & HDL-c (mmol/l) & TG (mmol/l) & LDL-c (mmo/l) \\
\hline S1S1 & 165 & $1.37(0.031)$ & $1.50(0.073)$ & $3.16(0.072)$ \\
S1S2 & 173 & $1.40(0.031)$ & $1.58(0.076)$ & $3.00(0.060)$ \\
S2S2 & 39 & $1.31(0.054)$ & $1.92(0.162)$ & $3.13(0.138)$ \\
& & $p=0.473$ & $p=0.041$ & $p=0.196$ \\
\hline
\end{tabular}

Data are expressed as the mean (SEM). Each $p$-value was based on an analysis of covariance.

significant difference was not found in TG levels in $L P L$ or APOC3 polymorphisms.

To determine the contribution of CETP and LPL gene polymorphisms to hyperalphacholesterolemia (2.58 $\mathrm{mmol} / \mathrm{l}$ or over) and hypoalphacholesterolemia $(1 \mathrm{mmol} /$ I or under), we divided all the participants into 3 groups according to HDL-cholesterol levels; $1 \mathrm{mmol} / \mathrm{l}$ or under, 1 to $2.58 \mathrm{mmol} / \mathrm{l}$, and $2.58 \mathrm{mmol} / \mathrm{l}$ or over. We then assessed the incidence of each genotype. The incidence of hyper- and hypoalphacholesterolemia was 1.8 and $8.3 \%$, respectively. Among the genes studied, we found 3 gene polymorphisms to be associated with the incidence of high HDL-cholesterol (2.58 $\mathrm{mmol} / \mathrm{l}$ or over)
Table 4. Demographic and lipid profile of female participants according to genotype.

CETP D442G (rs2303790)

\begin{tabular}{lrccc}
\hline Genotype & $n$ & HDL-c $(\mathrm{mmol} / \mathrm{l})$ & $\mathrm{TG}(\mathrm{mmol} / \mathrm{l})$ & $\mathrm{LDL}-\mathrm{c}(\mathrm{mmo} / \mathrm{l})$ \\
\hline wt & 440 & $1.58(0.018)$ & $1.128(0.0412)$ & $2.93(0.041)$ \\
hetero & 34 & $1.67(0.074)$ & $1.15(0.092)$ & $2.98(0.140)$ \\
& & $p=0.002$ & $p=0.590$ & $p=0.306$ \\
\hline
\end{tabular}

CETP TaqIB (rs708272)

\begin{tabular}{lrccc}
\hline Genotype & $n$ & HDL-c $(\mathrm{mmol} / \mathrm{l})$ & TG $(\mathrm{mmol} / \mathrm{l})$ & $\mathrm{LDL}-\mathrm{c}(\mathrm{mmo} / \mathrm{l})$ \\
\hline B1B1 & 183 & $1.58(0.028)$ & $1.13(0.057)$ & $2.93(0.062)$ \\
B1B2 & 220 & $1.67(0.026)$ & $1.15(0.066)$ & $2.98(0.059)$ \\
B2B2 & 72 & $1.75(0.043)$ & $0.92(0.057)$ & $2.85(0.105)$ \\
& & $p=0.004$ & $p=0.127$ & $p=0.461$ \\
\hline
\end{tabular}

LPL S447X (rs328)

\begin{tabular}{lrccc}
\hline Genotype & $n$ & HDL-c $(\mathrm{mmol} / \mathrm{l})$ & TG $(\mathrm{mmol} / \mathrm{l})$ & $\mathrm{LDL}-\mathrm{c}(\mathrm{mmo} / \mathrm{l})$ \\
\hline wt & 369 & $1.62(0.020)$ & $1.14(0.046)$ & $2.95(0.046)$ \\
hetero & 102 & $1.73(0.038)$ & $0.99(0.065)$ & $2.85(0.081)$ \\
homo & 4 & $1.97(0.164)$ & $0.72(0.177)$ & $3.89(0.321)$ \\
& & $p=0.010$ & $p=0.185$ & $p=0.054$ \\
\hline
\end{tabular}

LIPC 514CT (rs1800588)

\begin{tabular}{lcccc}
\hline Genotype & $n$ & HDL-c $(\mathrm{mmol} / \mathrm{l})$ & $\mathrm{TG}(\mathrm{mmol} / \mathrm{l})$ & $\mathrm{LDL}-\mathrm{c}(\mathrm{mmo} / \mathrm{l})$ \\
\hline $\mathrm{CC}$ & 102 & $1.59(0.041)$ & $1.15(0.089)$ & $2.93(0.086)$ \\
$\mathrm{CT}$ & 249 & $1.63(0.022)$ & $1.04(0.046)$ & $2.90(0.050)$ \\
TT & 124 & $1.73(0.037)$ & $1.20(0.091)$ & $3.03(0.090)$ \\
& & $p=0.014$ & $p=0.210$ & $p=0.406$ \\
\hline
\end{tabular}

\begin{tabular}{lrccc}
\multicolumn{5}{l}{ APOC3 SstI (rs5128) } \\
\hline Genotype & $n$ & HDL-c (mmol/l) & TG (mmol/l) & LDL-c (mmo/l) \\
\hline S1S1 & 207 & $1.65(0.028)$ & $1.05(0.054)$ & $2.90(0.062)$ \\
S1S2 & 208 & $1.62(0.026)$ & $1.18(0.067)$ & $2.93(0.059)$ \\
S2S2 & 60 & $1.75(0.045)$ & $1.08(0.079)$ & $3.03(0.106)$ \\
& & $p=0.078$ & $p=0.272$ & $p=0.608$ \\
\hline
\end{tabular}

Data are expressed as the mean (SEM). Each $p$-value was based on an analysis of covariance.

(Table 6). Participants with the B2B2 genotype of CETP TaqIB had a higher incidence of high HDL-cholesterol levels than the others. Heterozygotes of the CETP D442G polymorphism had a higher incidence of higher HDL-cholesterol levels than individuals with the wild type. Homozygotes of the LPL S447X polymorphism had a higher incidence of higher HDL-cholesterol levels than the others.

\section{Discussion}

In this study we have demonstrated the frequency of six common polymorphisms of four genes related to lipid 
Table 5. Age- and sex-adjusted means of all the participants according to genotype.

CETP D442G (rs2303790)

\begin{tabular}{|c|c|c|c|c|c|c|c|c|c|}
\hline \multirow[t]{2}{*}{ Genotype } & \multicolumn{3}{|c|}{ HDL-c (mmol/l) } & \multicolumn{3}{|c|}{$\mathrm{TG}(\mathrm{mmol} / \mathrm{l})$} & \multicolumn{3}{|c|}{ LDL-c (mmo/l) } \\
\hline & mean & low & upper & mean & low & upper & mean & low & upper \\
\hline wt & 1.53 & 1.49 & 1.56 & 1.37 & 1.29 & 1.45 & 3.05 & 2.98 & 3.11 \\
\hline hetero & 1.72 & 1.62 & 1.83 & 1.18 & 0.90 & 1.46 & 2.90 & 2.68 & 3.12 \\
\hline homo & 1.91 & 1.70 & 2.13 & 1.00 & 0.42 & 1.55 & 2.75 & 2.30 & 3.20 \\
\hline & \multicolumn{3}{|c|}{$p=0.0005$} & \multicolumn{3}{|c|}{$p=0.200$} & \multicolumn{3}{|c|}{$p=0.210$} \\
\hline \multicolumn{10}{|c|}{ CETP Int14 +1 G $\rightarrow \mathrm{A}(\mathrm{rs5742907)}$} \\
\hline \multirow[t]{2}{*}{ Genotype } & \multicolumn{3}{|c|}{ HDL-c (mmol/l) } & \multicolumn{3}{|c|}{$\mathrm{TG}(\mathrm{mmol} / \mathrm{l})$} & \multicolumn{3}{|c|}{ LDL-c (mmo/l) } \\
\hline & mean & low & upper & mean & low & upper & mean & low & upper \\
\hline wt & 1.54 & 1.51 & 1.57 & 1.35 & 1.27 & 1.43 & 3.04 & 2.97 & 3.10 \\
\hline \multirow[t]{2}{*}{ hetero } & 2.13 & 1.72 & 2.54 & 1.70 & 0.63 & 2.79 & 2.97 & 2.11 & 3.83 \\
\hline & \multicolumn{3}{|c|}{$p=0.0048$} & \multicolumn{3}{|c|}{$p=0.514$} & \multicolumn{3}{|c|}{$p=0.877$} \\
\hline \multicolumn{10}{|c|}{ CETP TaqIB (rs708272) } \\
\hline \multirow[t]{2}{*}{ Genotype } & \multicolumn{3}{|c|}{ HDL-c $(\mathrm{mmol} / \mathrm{l})$} & \multicolumn{3}{|c|}{$\mathrm{TG}(\mathrm{mmol} / \mathrm{l})$} & \multicolumn{3}{|c|}{ LDL-c (mmo/l) } \\
\hline & mean & low & upper & mean & low & upper & mean & low & upper \\
\hline B1B1 & 1.47 & 1.42 & 1.51 & 1.41 & 1.30 & 1.54 & 3.03 & 2.93 & 3.13 \\
\hline B1B2 & 1.56 & 1.53 & 1.59 & 1.34 & 1.25 & 1.42 & 3.04 & 2.97 & 3.10 \\
\hline \multirow[t]{2}{*}{ B2B2 } & 1.65 & 1.59 & 1.71 & 1.26 & 1.09 & 1.41 & 3.05 & 3.00 & 3.12 \\
\hline & \multicolumn{3}{|c|}{$p=0.0001$} & \multicolumn{3}{|c|}{$p=0.154$} & & $=0.87$ & \\
\hline LPL S447X & 328) & & & & & & & & \\
\hline Genotype & & $-c(m$ & & & $(\mathrm{mm}$ & & & $\mathrm{c}(\mathrm{mn}$ & \\
\hline & mean & low & upper & mean & low & upper & mean & low & upper \\
\hline wt & 1.53 & 1.49 & 1.56 & 1.38 & 1.30 & 1.47 & 3.03 & 2.96 & 3.10 \\
\hline hetero & 1.60 & 1.54 & 1.65 & 1.24 & 1.09 & 1.39 & 3.07 & 2.95 & 3.19 \\
\hline homo & 1.66 & 1.55 & 1.78 & 1.11 & 0.80 & 1.40 & 3.11 & 2.87 & 3.35 \\
\hline & & $=0.03$ & & & $=0.0 \mathrm{~s}$ & & & $=0.5$ & \\
\hline LIPC 514C & s18005 & & & & & & & & \\
\hline Genotype & & $-c(m)$ & & & (mm & & & $c(m n$ & \\
\hline & mean & low & upper & mean & low & upper & mean & low & upper \\
\hline $\mathrm{CC}$ & 1.48 & 1.46 & 1.51 & 1.33 & 1.26 & 1.40 & 3.05 & 3.00 & 3.10 \\
\hline CT & 1.54 & 1.52 & 1.56 & 1.35 & 1.31 & 1.39 & 3.04 & 3.01 & 3.07 \\
\hline$\pi$ & 1.59 & 1.57 & 1.62 & 1.37 & 1.30 & 1.44 & 3.02 & 2.97 & 3.07 \\
\hline & & $=0.00$ & & & $=0.7$ & & & $=0.5^{3}$ & \\
\hline APOC3 Sst & s5128) & & & & & & & & \\
\hline Genotype & & $-c(m$ & & & (mm & & & $\mathrm{c}(\mathrm{mn}$ & \\
\hline & mean & low & upper & mean & low & upper & mean & low & upper \\
\hline S1S1 & 1.55 & 1.51 & 1.60 & 1.30 & 1.18 & 1.41 & 3.04 & 2.95 & 3.13 \\
\hline S1S2 & 1.54 & 1.50 & 1.57 & 1.38 & 1.29 & 1.46 & 3.03 & 2.96 & 3.10 \\
\hline S2S2 & 1.52 & 1.45 & 1.58 & 1.45 & 1.29 & 1.63 & 3.02 & 2.89 & 3.16 \\
\hline & & $=0.42$ & & & $=0.1 \varepsilon$ & & & $=0.8$ & \\
\hline
\end{tabular}

Data are expressed as the mean (95\% confidence interval). Each $p$-value was based on an analysis of covariance.

metabolism and its incidence and association with serum lipid levels in the general Japanese population. Because this is the largest Japanese population ever analyzed, these data would be useful for future analyses on the general Japanese population.

The prevalence of the D442G and Int14 $+1 \mathrm{G} \rightarrow \mathrm{A}$ mutations is very high in the general Japanese population, with heterozygote frequencies of 7 and $1 \%$, respectively 
Table 6. Incidence of CETP TaqIB, D442G, and LPL S447X genetypes according to HDL levels.

\begin{tabular}{|c|c|c|c|c|}
\hline Genotype & & HDL-c (mmol/l) & & \\
\hline & $1.0>(8.3 \%)$ & $1.0 \leq, 2.58>(89.9 \%)$ & $2.58 \leq(1.8 \%)$ & $\dagger$ \\
\hline B1B1 & 72 (9.9\%) & $644(88.8 \%)$ & $9(1.2 \%)$ & $p=0.009$ \\
\hline B1B2 & 79 (8.2\%) & $870(90.2 \%)$ & $16(1.7 \%)$ & \\
\hline B2B2 & $15(4.8 \%)$ & $284(91.6 \%)$ & 11 (3.5\%) & \\
\hline \multicolumn{5}{|c|}{ CETP D442G } \\
\hline WT & $161(8.7 \%)$ & 1671 (89.8\%) & $29(1.6 \%)$ & $p=0.011$ \\
\hline Hetero & $5(3.6 \%)$ & 125 (91.2\%) & $7(5.1 \%)$ & \\
\hline Homo & $0(0 \%)$ & $2(100 \%)$ & $0(0 \%)$ & \\
\hline \multicolumn{5}{|c|}{ LPL S447X } \\
\hline WT & $134(8.9 \%)$ & 1354 (89.4\%) & $26(1.7 \%)$ & $p=0.002$ \\
\hline Hetero & $21(5.0 \%)$ & $390(93.3 \%)$ & $7(1.7 \%)$ & \\
\hline Homo & $2(8.0 \%)$ & $21(84.0 \%)$ & $2(8.0 \%)$ & \\
\hline
\end{tabular}

Column percentage is shown on top. Each box shows the number of participants in each category and its percentage in each genotype.

$\dagger$ The $\chi^{2}$-test was used.

$(10,11,27,28)$. Our large-scaled study showed similar frequencies of these mutations, with 8.1 and $0.6 \%$, respectively, indicating that our study population represents the general Japanese population and confirmed that the frequency of these mutations is quite high in Japanese. Because these mutations are associated with lower levels of CETP activity (27), the plasma level of HDL-cholesterol is higher in heterozygotes and homozygotes. We have also confirmed that the incidence of the mutation $\mathrm{D} 442 \mathrm{G}$ is higher in people with hyperalphalipoproteinemia (2.58 $\mathrm{mmol} / \mathrm{l}$ or over).

A genetic CETP deficiency is the most important and common cause of hyperalphalipoproteinemia in Japanese and contributes to $60 \%$ of hyperalphacholesterolemia (29). However, the role of CETP in atherogenesis is still under debate. A study in the Japanese Omagari area has shown a relatively increased incidence of coronary atherosclerosis in patients with CETP deficiency (30). In the Copenhagen City Heart Study, increased HDL-cholesterol levels caused by mutations in CETP were associated with an increased risk of CAD in caucasian females (31). In contrast, the B2 allele of the TaqIB polymorphism is associated with a low CETP mass, higher HDL-cholesterol levels, and a decreased risk of coronary artery disease (17). The reason for this discrepancy is unknown. Dose effects of CETP mass or another genetic abnormality may explain the difference in risk for CAD. Hirano et al. showed that people with weak LIPC activity had a higher incidence of CAD (32). Therefore, it is possible that LIPC activity is involved in these differ- ences. More studies are needed to determine the role of CETP in CAD in various populations with different genetic backgrounds.

Our study is consistent with others in terms of the allele frequency of the S447X polymorphism of the LPL gene $(19,20,33)$. Recent studies showed that the X447 mutation is associated with a favorable lipid profile, and lower TG and higher HDL-cholesterol levels, and that it may confer protection against coronary artery disease $(19,20$, 33). We also found a similar tendency in men and women. However, a significant change in HDL-cholesterol levels was found in the total population and women, but not in men. Because the X447 mutation is associated with stronger LPL activity, the TG levels were lower in heterozygotes and homozygotes as expected, although the difference was not significant in women. Homozygotes seem to have lower TG levels than heterozygotes, which reflects the gene dosage effect. Because carriers of S447X have a favorable lipid profile in terms of HDL-cholesterol and TG, and a decreased risk of $\operatorname{CAD}(35,36)$, we should examine whether carriers of S447X have fewer coronary artery events.

In terms of LIPC gene polymorphisms, our data clearly indicate that the frequency of the TT genotype is significantly higher in Japanese than in Caucasians $(37,38)$. However, a higher frequency of the TT genotype is also reported in Koreans and Japanese (39-41). Therefore, this difference might partly explain the higher HDL-cholesterol levels in Asians.

Our results on the allele frequency of the Sst1 polymor- 
phism of the $A P O C 3$ gene were almost comparable to the data on Asian Indians (42), but not on Caucasians (43). Caucasians seem to have a lower allele frequency of S2. Although a association of higher TG levels with the S2 allele has been reported in studies carried out in Caucasians (44-46) and Asians (47-49), our data show that such an association was found in the total population and in men, but not in women. Few other studies, however, have found any significant association between the Sst1 polymorphism and hypertriglyceridemia (50-52). The linkage disequilibrium between this polymorphism and the causative mutation might be weakened or absent in some populations (44).

Our data clearly showed that the heterozygotes of the D442G mutation, homozygotes of the LPL S447X mutation, and people with the TaqIB2B2 genotype had a higher incidence of hyperalphalipoproteinemia with HDLcholesterol levels of $2.58 \mathrm{mmol} / \mathrm{l}$ or over. Alcohol consumption and smoking can also affect the levels of HDLcholesterol. Corbex et al showed that the HDL levels of people with certain polymorphisms of the CETP gene are modulated by alcohol consumption (53). Therefore, it might be necessary to take into account environmental factors for the effect of gene polymorphisms on HDLcholesterol levels as well as on the risk of cardiovascular events.

In summary, we have provided the largest ever database of gene polymorphisms related to lipid metabolism in the general Japanese population. A prospective study is now under way to determine the contribution of these gene polymorphisms to cardiovascular risk in Japanese.

Acknowledgements: We thank Shizuya Yamashita (Osaka University) and Hideaki Bujo (Chiba University) for critical reading of the manuscript. This study was supported by research grants for health sciences from the Japanese Ministry of Health and a grant from the Japan Atherosclerosis Society. We also thank the Osaka Pharmaceutical Manufacturer's Association for supporting our work.

\section{Appendix}

\section{Research Group on Serum Lipid Survey 2000 in} Japan

Chairman: Toru Kita, Department of Cardiovascular Medicine, Kyoto University Graduate School of Medicine Principal investigators: Akira Yamamoto, National Cardiovascular Center

Yuji Matsuzawa, Department of Internal Medicine, Osaka University

Yasushi Saito, Department of Internal Medicine, Chiba University

Shinichi Oikawa, Department of Internal Medicine, Nippon Medical School
Noriaki Nakaya, Fussa Hospital

Jun Sasaki, International University of Health and Welfare

Hiroshi Mabuchi, Department of Internal Medicine, Kanazawa University

Nobuhiro Yamada, Department of Internal Medicine, Tsukuba University

Hiroshige Itakura, Ibaraki Christian University

Yuichi Ishikawa, Faculty of Health Sciences, Kobe University

Tadayoshi Ouchi, Department of Geriatric Medicine, University of Tokyo

Hiroshi Horibe, Keisen Clinic

Tamio Teramoto, Department of Internal Medicine, Teikyo University

Hidenori Arai, Department of Geriatric Medicine, Kyoto University

Collaborators: Tohru Egashira and Hiroaki Hattori, Department of Advanced Technology and Development, BML, Inc.

Nobuo Shirahashi, Osaka City University Medical School

\section{References}

(1) Murray CJ and Lopez AD: Mortality by cause for eight regions of the world: Global Burden of Disease Study. Lancet, 349: 1269-1276, 1997

(2) Watanabe H, Yamane K, Fujikawa R, Okubo M, Egusa G, and Kohno N: Westernization of lifestyle markedly increases carotid intima-media wall thickness (IMT) in Japanese people. Atherosclerosis, 166: 67-72, 2003

(3) Marmot MG, Syme SL, Kagan A, Kato H, Cohen $\mathrm{JB}$, and Belsky J: Epidemiologic studies of coronary heart disease and stroke in Japanese men living in Japan, Hawaii and California: prevalence of coronary and hypertensive heart disease and associated risk factors. Am J Epidemiol, 102: 514525, 1975

( 4 ) Rader DJ, Cohen J, and Hobbs HH: Monogenic hypercholesterolemia: new insights in pathogenesis and treatment. J Clin Invest, 111: 1795-1803, 2003

( 5 ) Austin MA, Hutter CM, Zimmern RL, and Humphries SE: Familial hypercholesterolemia and coronary heart disease: a HuGE association review. Am J Epidemiol, 160: 421-429, 2004

(6) Gaziano JM, Hennekens CH, O’Donnell CJ, Breslow $\mathrm{JL}$, and Buring JE: Fasting triglycerides, high-density lipoprotein, and risk of myocardial infarction. Circulation, 96: 2520-2525, 1997

( 7 ) Arai H, Yamamoto A, Matsuzawa Y, Saito Y, Yamada N, Oikawa S, Mabuchi H, Teramoto T, Sasaki J, Nakaya N, Itakura H, Ishikawa Y, Ouchi $Y$, Horibe H, and Kita T: Serum Lipid Survey and its recent trend in the General Japanese Population in 
2000. J Atheroscler Thromb, 12, 98-106, 2005

( 8 ) Yen FT, Deckelbaum RJ, Mann CJ, Marcel YL, Milne RW, and Tall AR: Inhibition of cholesteryl ester transfer protein activity by monoclonal antibody. Effects on cholesteryl ester formation and neutral lipid mass transfer in human plasma. J Clin Invest, 83: 20182024, 1989

( 9 ) Brown ML, Inazu A, Hesler CB, Agellon LB, Mann C, Whitlock ME, Marcel YL, Milne RW, Koizumi J, Mabuchi $\mathrm{H}$, et al.: Molecular basis of lipid transfer protein deficiency in a family with increased highdensity lipoproteins. Nature, 342: 448-451, 1989

(10) Inazu A, Brown ML, Hesler CB, Agellon LB, Koizumi J, Takata K, Maruhama Y, Mabuchi $\mathrm{H}$, and Tall AR: Increased high-density lipoprotein levels caused by a common cholesteryl-ester transfer protein gene mutation. N Engl J Med, 323: 1234-1238, 1990

(11) Hirano K, Yamashita S, Funahashi T, Sakai N, Menju M, Ishigami M, Hiraoka H, Kameda-Takemura K, Tokunaga $\mathrm{K}$, Hoshino $\mathrm{T}$, et al.: Frequency of intron 14 splicing defect of cholesteryl ester transfer protein gene in the Japanese general population - relation between the mutation and hyperalphalipoproteinemia. Atherosclerosis, 100: 85-90, 1993

(12) Nagano M, Yamashita S, Hirano K, Kujiraoka T, Ito M, Sagehashi Y, Hattori H, Nakajima N, Maruyama T, Sakai N, Egashira T, and Matsuzawa Y: Point mutation $(-69 \mathrm{G} \rightarrow \mathrm{A})$ in the promoter region of cholesteryl ester transfer protein gene in Japanese hyperalphalipoproteinemic subjects. Arterioscler Thromb Vasc Biol, 21: 985-990, 2001

(13) Sakai N, Yamashita S, Hirano K, Menju M, Arai T, Kobayashi K, Ishigami M, Yoshida Y, Hoshino T, Nakajima N, et al.: Frequency of exon 15 missense mutation (442D:G) in cholesteryl ester transfer protein gene in hyperalphalipoproteinemic Japanese subjects. Atherosclerosis, 114: 139-145, 1995

(14) Tall AR: Plasma cholesteryl ester transfer protein. J Lipid Res, 34: 1255-1274, 1993

(15) Wang S, Deng L, Milne RW, and Tall AR: Identification of a sequence within the C-terminal 26 amino acids of cholesteryl ester transfer protein responsible for binding a neutralizing monoclonal antibody and necessary for neutral lipid transfer activity. J Biol Chem, 267: 17487-17490, 1992

(16) Hannuksela ML, Liinamaa MJ, Kesaniemi YA, and Savolainen MJ: Relation of polymorphisms in the cholesteryl ester transfer protein gene to transfer protein activity and plasma lipoprotein levels in alcohol drinkers. Atherosclerosis, 110: 35-44, 1994

(17) Ordovas JM, Cupples LA, Corella D, Otvos JD, Osgood D, Martinez A, Lahoz C, Coltell O, Wilson PW, and Schaefer EJ: Association of cholesteryl ester transfer protein-TaqIB polymorphism with variations in lipoprotein subclasses and coronary heart disease risk: the Framingham study. Arterioscler Thromb Vasc Biol, 20: 1323-1329, 2000

(18) Stocks J, Thorn JA, and Galton DJ: Lipoprotein lipase genotypes for a common premature termination codon mutation detected by PCR-mediated site-directed mutagenesis and restriction digestion. J Lipid Res, 33: 853-857, 1992

(19) Kuivenhoven JA, Groenemeyer BE, Boer JM, Reymer PW, Berghuis R, Bruin T, Jansen H, Seidell $\mathrm{JC}$, and Kastelein JJ: Ser447stop mutation in lipoprotein lipase is associated with elevated HDL cholesterol levels in normolipidemic males. Arterioscler Thromb Vasc Biol, 17: 595-599, 1997

(20) Groenemeijer BE, Hallman MD, Reymer PW, Gagne $\mathrm{E}$, Kuivenhoven JA, Bruin T, Jansen $\mathrm{H}$, Lie KI, Bruschke AV, Boerwinkle E, Hayden MR, and Kastelein JJ: Genetic variant showing a positive interaction with beta-blocking agents with a beneficial influence on lipoprotein lipase activity, HDL cholesterol, and triglyceride levels in coronary artery disease patients. The Ser447-stop substitution in the lipoprotein lipase gene. REGRESS Study Group. Circulation, 95: 2628-2635, 1997

(21) Bensadoun A and Berryman DE: Genetics and molecular biology of hepatic lipase. Curr Opin Lipidol, 7: 77-81, 1996

(22) Zambon A, Deeb SS, Hokanson JE, Brown BG, and Brunzell JD: Common variants in the promoter of the hepatic lipase gene are associated with lower levels of hepatic lipase activity, buoyant LDL, and higher HDL2 cholesterol. Arterioscler Thromb Vasc Biol, 18: 1723-1729, 1998

(23) Ordovas JM, Civeira F, Genest J, Jr., Craig S, Robbins AH, Meade T, Pocovi M, Frossard PM, Masharani U, Wilson PW, et al.: Restriction fragment length polymorphisms of the apolipoprotein A-I, C-III, A-IV gene locus. Relationships with lipids, apolipoproteins, and premature coronary artery disease. Atherosclerosis, 87: 75-86, 1991

(24) Anderson RA, Burns TL, Lee J, Swenson D, and Bristow JL: Restriction fragment length polymorphisms associated with abnormal lipid levels in an adolescent population. Atherosclerosis, 77: 227237, 1989

(25) Johnson CL, Rifkind BM, Sempos CT, Carroll MD, Bachorik PS, Briefel RR, Gordon DJ, Burt VL, Brown CD, Lippel K, et al.: Declining serum total cholesterol levels among US adults. The National Health and Nutrition Examination Surveys. Jama, 269: 3002-3008, 1993

(26) Nagano M, Yamashita S, Hirano K, Ito M, Maruyama $\mathrm{T}$, Ishihara M, Sagehashi Y, Oka T, Kujiraoka T, Hattori H, Nakajima N, Egashira T, Kondo M, Sakai $\mathrm{N}$, and Matsuzawa Y: Two novel missense mutations in the CETP gene in Japanese hyperalphalipo- 
proteinemic subjects: high-throughput assay by Invader assay. J Lipid Res, 43: 1011-1018, 2002

(27) Inazu A, Jiang XC, Haraki T, Yagi K, Kamon N, Koizumi J, Mabuchi H, Takeda R, Takata K, Moriyama $\mathrm{Y}$, et al.: Genetic cholesteryl ester transfer protein deficiency caused by two prevalent mutations as a major determinant of increased levels of high density lipoprotein cholesterol. J Clin Invest, 94: 1872-1882, 1994

(28) Inazu A, Koizumi J, Haraki T, Yagi K, Wakasugi T, Takegoshi T, Mabuchi H, and Takeda R: Rapid detection and prevalence of cholesteryl ester transfer protein deficiency caused by an intron 14 splicing defect in hyperalphalipoproteinemia. Hum Genet, 91: 13-16, 1993

(29) Sakai N, Santamarina-Fojo S, Yamashita S, Matsuzawa $Y$, and Brewer HB, Jr: Exon 10 skipping caused by intron 10 splice donor site mutation in cholesteryl ester transfer protein gene results in abnormal downstream splice site selection. J Lipid Res, 37: 2065-2073, 1996

(30) Hirano K, Yamashita S, Nakajima N, Arai T, Maruyama T, Yoshida Y, Ishigami M, Sakai N, Kameda-Takemura K, and Matsuzawa Y: Genetic cholesteryl ester transfer protein deficiency is extremely frequent in the Omagari area of Japan. Marked hyperalphalipoproteinemia caused by CETP gene mutation is not associated with longevity. Arterioscler Thromb Vasc Biol, 17: 1053-1059, 1997

(31) Agerholm-Larsen B, Nordestgaard BG, Steffensen $R$, Jensen $G$, and Tybjaerg-Hansen A: Elevated HDL cholesterol is a risk factor for ischemic heart disease in white women when caused by a common mutation in the cholesteryl ester transfer protein gene. Circulation, 101: 1907-1912, 2000

(32) Hirano K, Yamashita S, Kuga Y, Sakai N, Nozaki S, Kihara S, Arai T, Yanagi K, Takami S, Menju M, et al.: Atherosclerotic disease in marked hyperalphalipoproteinemia. Combined reduction of cholesteryl ester transfer protein and hepatic triglyceride lipase. Arterioscler Thromb Vasc Biol, 15: 1849-1856, 1995

(33) Hata A, Robertson M, Emi M, and Lalouel JM: Direct detection and automated sequencing of individual alleles after electrophoretic strand separation: identification of a common nonsense mutation in exon 9 of the human lipoprotein lipase gene. Nucleic Acids Res, 18: 5407-5411, 1990

(34) Mattu RK, Needham EW, Morgan R, Rees A, Hackshaw AK, Stocks J, Elwood PC, and Galton DJ: DNA variants at the LPL gene locus associate with angiographically defined severity of atherosclerosis and serum lipoprotein levels in a Welsh population. Arterioscler Thromb, 14: 1090-1097, 1994

(35) Gagne SE, Larson MG, Pimstone SN, Schaefer EJ,
Kastelein JJ, Wilson PW, Ordovas JM, and Hayden MR: A common truncation variant of lipoprotein lipase (Ser447X) confers protection against coronary heart disease: the Framingham Offspring Study. Clin Genet, 55: 450-454, 1999

(36) Peacock RE, Hamsten A, Nilsson-Ehle P, and Humphries SE: Associations between lipoprotein lipase gene polymorphisms and plasma correlations of lipids, lipoproteins and lipase activities in young myocardial infarction survivors and age-matched healthy individuals from Sweden. Atherosclerosis, 97: 171-185, 1992

(37) Anderson JL and Carlquist JF: Genetic polymorphisms of hepatic lipase and cholesteryl ester transfer protein, intermediate phenotypes, and coronary risk: do they add up yet? J Am Coll Cardiol, 41: 1990-1993, 2003

(38) Couture P, Otvos JD, Cupples LA, Lahoz C, Wilson PW, Schaefer EJ, and Ordovas JM: Association of the C-514T polymorphism in the hepatic lipase gene with variations in lipoprotein subclass profiles: The Framingham Offspring Study. Arterioscler Thromb Vasc Biol, 20: 815-822, 2000

(39) Yamakawa-Kobayashi K, Somekawa Y, Fujimura M, Tomura S, Arinami T, and Hamaguchi H: Relation of the $-514 \mathrm{C} / \mathrm{T}$ polymorphism in the hepatic lipase gene to serum HDL and LDL cholesterol levels in postmenopausal women under hormone replacement therapy. Atherosclerosis, 162: 17-21, 2002

(40) Somekawa Y, Umeki H, Kobayashi K, Tomura S, Aso $\mathrm{T}$, and Hamaguchi $\mathrm{H}$ : Effects of hormone replacement therapy and hepatic lipase polymorphism on serum lipid profiles in postmenopausal Japanese women. J Clin Endocrinol Metab, 87: 4766-4770, 2002

(41) Hong SH, Song J, and Kim JQ: Genetic variations of the hepatic lipase gene in Korean patients with coronary artery disease. Clin Biochem, 33: 291-296, 2000

(42) Chhabra S, Narang R, Krishnan LR, Vasisht S, Agarwal DP, Srivastava LM, Manchanda SC, and Das N: Apolipoprotein C3 SstI polymorphism and triglyceride levels in Asian Indians. BMC Genet, 3: 9, 2002

(43) Hoffer MJ, Sijbrands EJ, De Man FH, Havekes LM, Smelt AH, and Frants RR: Increased risk for endogenous hypertriglyceridaemia is associated with an apolipoprotein C3 haplotype specified by the SstI polymorphism. Eur J Clin Invest, 28: 807-812, 1998

(44) Shoulders CC, Grantham TT, North JD, Gaspardone A, Tomai F, de Fazio A, Versaci F, Gioffre PA, and Cox NJ: Hypertriglyceridemia and the apolipoprotein CIII gene locus: lack of association with the variant insulin response element in Italian school children. Hum Genet, 98: 557-566, 1996 
(45) Dallinga-Thie GM, van Linde-Sibenius Trip M, Rotter JI, Cantor RM, Bu X, Lusis AJ, and de Bruin TW: Complex genetic contribution of the Apo AI-CIIIAIV gene cluster to familial combined hyperlipidemia. Identification of different susceptibility haplotypes. J Clin Invest, 99: 953-961, 1997

(46) Paul-Hayase H, Rosseneu M, Robinson D, Van Bervliet JP, Deslypere JP, and Humphries SE: Polymorphisms in the apolipoprotein (apo) AI-CIII-AIV gene cluster: detection of genetic variation determining plasma apo AI, apo CIII and apo AIV concentrations. Hum Genet, 88: 439-446, 1992

(47) Ko YL, Ko YS, Wu SM, Teng MS, Chen FR, Hsu TS, Chiang CW, and Lee YS: Interaction between obesity and genetic polymorphisms in the apolipoprotein CIII gene and lipoprotein lipase gene on the risk of hypertriglyceridemia in Chinese. Hum Genet, 100: 327-333, 1997

(48) Hong SH, Park WH, Lee CC, Song JH, and Kim JQ: Association between genetic variations of apo AICIII-AIV cluster gene and hypertriglyceridemic subjects. Clin Chem, 43: 13-17, 1997

(49) Zeng Q, Dammerman M, Takada Y, Matsunaga A, Breslow JL, and Sasaki J: An apolipoprotein CIII marker associated with hypertriglyceridemia in Caucasians also confers increased risk in a west Japanese population. Hum Genet, 95: 371-375, 1995

(50) Price WH, Morris SW, Burgon R, Donald PM, and Kitchin AH: Apolipoprotein CIII polymorphism and coronary heart disease. Lancet, 2: 1041, 1986

(51) Marcil M, Boucher B, Gagne E, Davignon J, Hayden $M$, and Genest J, Jr: Lack of association of the apolipoprotein A-I-C-III-A-IV gene Xmnl and SstI polymorphisms and of the lipoprotein lipase gene mutations in familial combined hyperlipoproteinemia in French Canadian subjects. J Lipid Res, 37: 309319, 1996

(52) Bai H, Saku K, Liu R, Imamura M, and Arakawa K: Association between coronary heart disease and the apolipoprotein A-I/C-III/A-IV complex in a Japanese population. Hum Genet, 95: 102-104, 1995

(53) Corbex M, Poirier O, Fumeron F, Betoulle D, Evans A, Ruidavets JB, Arveiler D, Luc G, Tiret L, and Cambien F: Extensive association analysis between the CETP gene and coronary heart disease phenotypes reveals several putative functional polymorphisms and gene-environment interaction. Genet Epidemiol, 19: 64-80, 2000 